\title{
RICHNESS AND DIVERSITY OF APHIDS (HOMOPTERA, APHIDIDAE) ALONG AN ALTITUDINAL GRADIENT IN THE SERRA DO MAR, PARANÁ, BRAZIL ${ }^{1}$
}

\author{
Crisleide Maria Lazzarotto ${ }^{2}$ \\ Sonia Maria Noemberg Lázzari ${ }^{2}$
}

\begin{abstract}
The lack of bioecological studies on aphids in regions with complex floristic and faunistic structure, such as the Atlantic Tropical Rain Forest, lead to the initiation of this research. The objectives were to determine species richness and diversity of aphids and to investigate the influence of altitude and environmental perturbations on aphid populations. The collections were made with yellow pan traps at 11 sites with altitudes from $-10 \mathrm{~m}$ to $1000 \mathrm{~m}$ above sea level (a.s.l.), in the Serra do Mar, Paraná, Brazil, from December 1993 to December 1994. Richness and diversity of aphids were greatest at $85 \mathrm{~m}$ a.s.l. This site was characterized by three distinct floral communities: primary vegetation, secondary vegetation in successional stages, and secondary vegetation subject to regular mowing. No pattern in the number or kinds of species could be established along the altitudinal gradient. These results, indicate that several factors interact, but especially floristic composition and climatic conditions, to determine aphidofauna richness and diversity in this region of the Atlantic Tropical Rain Forest.

KEY WORDS. aphids, diversity, equitability, richness, altitude
\end{abstract}

The Serra do Mar, in Paraná, contains part of the Atlantic Tropical Rain Forest, which extends along the coast from the northeast to the south of Brazil; it is very important in terms of diversity, housing a great variety of animal and plant species and must be treated as a valuable conservation area (COX \& MOORE 1993; PRANCE 1995).

Faunistic richness and diversity, especially of insects, are related to several different biotic and abiotic factors. According to COX \& MOORE (1993), the richness in the rain forest is, in general, a consequence of high productivity in tropical latitudes and high structural complexity, supporting many species of small invertebrates. LAWTON (1983) proposed that the diversity of phytophagous insects results from the diversity of plant resources, thus the higher the vegetational structural complexity, the higher the insect richness. ODUM (1983) stated that diversity includes both the number of species and the density of each species; thus, well balanced ecosystems with low incidence of dominant species are more likely to reach high diversity. VAN DOBLEN \& LOWE-MCCONNELL (1975) apud ODUM (1983), mentioned that stable ecosystems promote high diversity, but the opposite is not necessarily true. HUSTON (1979) concluded that periodically disturbed

1) Contribuição número 1030 do Departamento de Zoologia, Universidade Federal do Paraná.

2) Departamento de Zoologia, Universidade Federal do Paraná. Caixa Postal 19020 , 81531-990 Curitiba, Paraná, Brasil. Bolsista do CNPq. 
systems tend to present higher diversity than ecosystems in equilibrium, where dominance and competitive exclusion are more noticeable.

In relation to the distribution and number of species along altitudinal gradients, FERNANDES \& PRICE (1991) indicated that the richness of animal species, including gall forming aphids, is lower at higher elevations.

Despite the great scientific and social value of the Atlantic Forest, research on its fauna, especially of small insects, such as aphids, is lacking. This research was carried out to contribute to the study of the Brazilian aphidofauna and to determine species richness and diversity of aphids along an altitudinal gradient in the Serra do Mar, Paraná.

\section{MATERIALS AND METHODS}

Aphids were collected with yellow pan traps (Möericke type) from 11 sites along an altitudinal gradient, ranging from $-10 \mathrm{~m}$ to $1000 \mathrm{~m}$ above sea level (a.s.l.), at Serra do Mar, Paraná, for one year, from December 1993 to December 1994. Five sites (1-5) were at the Agronomic Institute of Paraná experimental station (IAPAR I), located on PR 410 road, by the km 8.2 from Highway 277, in Morretes county; four were located along Estrada da Graciosa road, in Quatro Barras and Morretes counties, all distances were taken from Highway BR 116. The two other sites were along the Highway BR 277, between Curitiba and Paranaguá.

The climate in this region is described based on Köppen's system (INSTITUTO AGRONÔMICO DO PARANÁ 1994), as Af-superhumid tropical (year average rainfall of $2000 \mathrm{~mm}$ ), without dry season, annual average temperature between 17 and $18^{\circ} \mathrm{C}$, and absence of frost. A brief description of each site follows.

Sites 1 ( $-10 \mathrm{~m}$ a.s.l., a swamp at the IAPAR experimental station) and $2(10$ $\mathrm{m}$ a.s.l., at the garden of the IAPAR station) are lowland dense ombrophilous forest, where herbaceous Asteraceae and Poaceae predominate, influenced by the secondary forest. Sites 3 ( $20 \mathrm{~m}$ a.s.l., by a citrus orchard, at the IAPAR station), 4 (65 m a.s.l., by the woods, at the IAPAR station), 5 ( $78 \mathrm{~m}$ a.s.l., on the hill top, at the IAPAR station), 6 ( $85 \mathrm{~m}$ a.s.I., on $\mathrm{km} 22$ of Estrada da Graciosa road, in Quatro Barras county), and 8 (190 m a.s.l., on km 16.8 of Estrada da Graciosa road, in Quatro Barras county, by the resting area Recanto Mãe Catira), representing secondary submontane dense ombrophilous forest, composed mainly by Poaceae, Asteraceae, Melastomataceae, and many different kinds of trees. Site 7 (185 m a.s.l., on km 35 of the Highway 277, in Morretes county) is a transitional area between the dense montane ombrophilous forest and the mixed ombrophilous forest. The trap on site 9 (555 m a.s.l., on km 10,1 of Estrada da Graciosa road, in Quatro Barras county, by the resting area Bela Vista) was surrounded by dense submontane ombrophilous forest in advanced secondary succession, with cultivated and native trees around. The other two sites, 10 (750 m a.s.l., on km 0,5 of Estrada da Graciosa road, in Morretes county) and 11 (1000 m a.s.l., on km 53,5 of Highway BR277, in São José dos Pinhais county) are dense montane ombrophilous forest; the first being transitional with mixed Araucaria forest and the last an open area on the top of the mountain, surrounded by secondary vegetation. 
The traps were made of round yellow plastic bowls with brown margins. Four screened holes at the sides were made to minimize overflow due to rainfall. The content consisted of $2.5 \mathrm{l}$ of water, a few drops of detergent, and $10 \mathrm{ml}$ of $10 \%$ formaldehyde, to preserve the insects. Aphids were removed every two weeks, with a fine brush and placed in labeled vials containing $70 \%$ ethanol. In the laboratory, specimens were mounted in balsam (MARTIN 1983) and identified under a compound microscope using several identification keys (HOLMAN 1974; BLACKMAN \& EASTOP 1984; Millar 1990; Costa et al. 1993). Microscope slides of identified aphids were deposited in the Coleção de Entomologia Pe. J.S. Moure, Departamento de Zoologia, Universidade Federal do Paraná (DZUP).

According to MAGURRAN (1988), the most commonly used diversity index is the Shannon Index, due to the computational ease. This index assumes random sampling, with all the species represented. However, for selective, non-random sampling, in which species probably will not be collected, the Brillouin Index is more appropriate; thus, it was used in this study to calculate diversity and equitability, according to the following formula:

Diversity $H B=\frac{\ln N !-\ln n_{i} !}{N}$

where: $(N)$ total number of individuals; $\left(\mathrm{n}_{\mathrm{i}}\right)$ number of individuals from species $\mathrm{i}$.

Equitability $E=\frac{H B}{H B_{\max }}$

where: $H B_{\max }=1 / N \ln \left(\frac{N !}{\{[N / S] !\}^{s-r}\{([N / S]+1) !\}^{r}}\right)$

(S) total number of species, ([N/S]) the whole N/S, $r=N-S$ [N/S ]

\section{RESULTS AND DISCUSSION}

A total of 8,019 aphid specimens, representing 87 species, were collected in the traps during the one year sampling period (Tab. I).

Despite the usual high species richness in tropical forests, perhaps primarily due to high productivity and structural complexity (COX \& MOORE 1993), the number of aphid species collected during our study represented only $2.2 \%$ of the world aphidofauna and $76 \%$ of the Brazilian aphid species recorded to date (COSTA et al. 1993). Diversity of aphids depends mainly on the vegetational diversity, temperature and moisture (AGARWALA \& GHOSH 1985). The diversity of host plants should determine the diversity of aphids; however, a highly diverse flora could negatively affect aphid diversity due to their low efficiency in locating their host plants (DIXON et al. 1987; DIXON \& KINDLMANN 1990). On the other hand, LAWTON (1983) stated that the diversity of phytophagous insects increases with increasing structural complexity of the plants, such that a tree has more niches to house different insect species than a gramineous plant. However, this aspect of aphid species richness was not investigated during this study. 
Table I. List of aphid species and total number of alate collected with yellow pan traps in eleven sites in the Serra do Mar, Paraná, Brazil, from December 1993 to December 1994 (sites 01 to 09 and 11) and from April 1994 to December 1994 (site 10). Altitudinal values in meters above sea level.

\begin{tabular}{|c|c|c|c|c|c|c|c|c|c|c|c|c|}
\hline \multirow{2}{*}{ Species } & \multicolumn{12}{|c|}{ Sites (Altitude m a.s.I.) } \\
\hline & $\begin{array}{c}1 \\
(-10)\end{array}$ & $\begin{array}{c}2 \\
(10)\end{array}$ & $\begin{array}{c}3 \\
(20)\end{array}$ & $\begin{array}{c}4 \\
(65)\end{array}$ & $\begin{array}{c}5 \\
(78)\end{array}$ & $\begin{array}{c}6 \\
(85)\end{array}$ & $\begin{array}{c}7 \\
(185)\end{array}$ & $\begin{array}{c}8 \\
(190)\end{array}$ & $\begin{array}{c}9 \\
(550)\end{array}$ & $\begin{array}{c}10 \\
(750)\end{array}$ & $\begin{array}{c}11 \\
(1000)\end{array}$ & Total \\
\hline Acyrthosiphon bidenticola Smith, 1961 & 4 & - & 1 & 5 & 9 & 29 & 3 & 4 & 14 & - & 1 & 70 \\
\hline Acyrthosiphon kondoi Shinji, 1938 & - & - & 1 & - & - & - & - & - & - & - & - & 1 \\
\hline Acyrthosiphon malvae (Mosley, 1841) & - & - & - & 1 & - & - & - & - & 2 & - & - & 3 \\
\hline Acyrthosiphon pisum (Harris, 1776) & - & - & - & - & 5 & 2 & - & - & - & - & - & 7 \\
\hline Aphis coreopsidis (Thomas, 1878) & 1 & 2 & 9 & 10 & 104 & 2 & 2 & 2 & - & - & 2 & 134 \\
\hline Aphis fabae Scopoli, 1763 & - & 1 & - & - & 1 & - & - & - & - & 3 & 1 & 6 \\
\hline Aphis fabae (group) & - & - & - & - & 2 & - & - & - & - & - & - & 2 \\
\hline Aphis forbesi Wood, 1889 & - & 1 & - & - & - & - & - & - & 1 & - & 1 & 3 \\
\hline Aphis gossypii Glover, 1877 & 48 & 45 & 17 & 13 & 171 & 43 & 73 & 13 & 22 & 15 & - & 460 \\
\hline Aphis nerii Boyer de Fonscolombe, 1841 & 9 & 5 & 5 & 8 & 71 & 3 & 8 & - & - & - & - & 109 \\
\hline Aphis sambuci Linnaeus, 1758 & - & - & - & - & 3 & - & - & 1 & 19 & - & - & 23 \\
\hline Aphis sedi Kaltenbach, 1843 & 1 & 1 & 1 & - & 7 & 1 & - & 1 & - & - & - & 12 \\
\hline Aphis solanella Theobald, 1914 & 1 & 4 & 10 & 10 & 84 & 1 & 11 & - & - & 3 & 1 & 125 \\
\hline Aphis spiraecola Patch, 1914 & 308 & 403 & 181 & 79 & 379 & 85 & 345 & 134 & 92 & 152 & 35 & 2193 \\
\hline Aphis terricola Rondani, 1847 & - & - & 1 & - & - & - & - & - & - & - & - & 1 \\
\hline Aphis spp. (8 spp.) & - & 1 & 1 & 1 & 4 & 2 & - & - & 1 & 1 & 1 & 12 \\
\hline Aulacorthum solani (Kaltenbach, 1843) & - & 2 & 1 & - & 9 & 8 & 3 & 18 & 22 & 2 & 4 & 69 \\
\hline Brachycaudus helicrysi (Kaltenbach, 1843) & 5 & 20 & 9 & 3 & 86 & 2 & - & 1 & 18 & 1 & 9 & 154 \\
\hline Brachycaudus rumexicolens (Patch, 1917) & - & - & - & 1 & - & - & - & - & - & - & - & 1 \\
\hline Brachycaudus schwartzi (Börner, 1931) & 1 & - & - & - & - & 1 & - & - & - & - & - & 2 \\
\hline Brevicoryne brassicae (Linnaeus, 1758) & 5 & 18 & 11 & 59 & 14 & 57 & 10 & 10 & 87 & 11 & 167 & 449 \\
\hline Capitophorus elaeagni (del Guercio, 1894) & - & 1 & - & - & 10 & - & - & - & - & - & - & 11 \\
\hline Capitophorus hippophaes (Walker, 1853) & 4 & 7 & 2 & - & 25 & 6 & 1 & 3 & 5 & - & - & 53 \\
\hline Carolinaia caricis Wilson, 1911 & - & - & - & - & - & - & - & - & - & - & 1 & 1 \\
\hline Cavariella aegopodii (Scopoli, 1763) & - & - & - & - & 3 & 4 & 1 & - & 4 & - & - & 12 \\
\hline Cerataphis variabilis Hille Ris Lambers, 1953 & - & - & - & 1 & - & - & 4 & 1 & - & - & - & 6 \\
\hline Cinara maritimae (Dufour, 1833) & - & - & - & - & - & 1 & - & - & 1 & - & - & 2 \\
\hline Coloradoa rufomaculata (Wilson, 1923) & 1 & - & - & - & - & 1 & - & - & 1 & 1 & 1 & 5 \\
\hline Dysaphis aucupariae (Buckton, 1879) & - & - & - & 1 & - & 2 & - & - & - & - & - & 3 \\
\hline Dysaphis foeniculus (Theobald, 1923) & - & 1 & - & - & - & 1 & - & - & - & - & - & 2 \\
\hline Eulachnus rileyi (Wilson, 1911) & - & 1 & - & 4 & - & 1 & 14 & - & 2 & - & 5 & 27 \\
\hline Geoica lucifuga (Zehtner, 1897) & - & - & - & - & - & - & - & - & - & - & 2 & 2 \\
\hline Geopemphigus floccosus (Moreira, 1925 & 13 & 6 & 2 & - & 2 & 31 & 12 & 2 & 16 & - & - & 84 \\
\hline Hyadaphis foeniculi (Passerini, 1860) & - & 1 & - & - & 1 & - & - & - & - & - & - & 2 \\
\hline Hyperomyzus carduellinus (Theobald, 1915) & - & - & - & - & - & - & - & - & - & - & 1 & 1 \\
\hline Hyperomyzus lactucae (Linnaeus, 1768) & 2 & - & - & 1 & 9 & 2 & - & - & 2 & - & 1 & 17 \\
\hline Lipaphis erysimi (Kaltenbach, 1843) & 22 & 11 & 6 & 10 & 294 & 120 & 6 & 2 & 43 & - & 8 & 522 \\
\hline Lizerius cermelii Quednau, 1974 & - & - & - & - & - & - & 2 & - & - & - & - & 2 \\
\hline Lizerius intermedius Quednau, 1974 & - & - & - & - & - & 1 & - & - & - & - & - & 1 \\
\hline Lizerius tuberculatus (E.E. Blanchard, 1939) & - & 1 & - & - & - & 1 & 2 & - & - & 1 & - & 5 \\
\hline Macrosiphini ( 3 spp.) & - & - & - & 1 & - & - & - & - & 1 & - & 1 & 3 \\
\hline Macrosiphoniella yomogifoliae (Shinji, 1924) & - & - & - & - & 1 & - & - & - & - & - & 1 & 2 \\
\hline Macrosiphum euphorbiae (Thomas, 1878) & 1 & - & - & - & - & - & 1 & - & - & - & - & 2 \\
\hline Melanaphis sacchari (Zehtner, 1897) & - & - & - & - & - & - & - & - & 1 & - & - & 1 \\
\hline Metopolophium dirhodum (Walker, 1849) & - & - & - & - & 2 & - & - & - & - & - & - & 2 \\
\hline Microparsus brasiliensis (Moreira, 1925) & - & - & - & - & - & 2 & 3 & - & - & - & - & 5 \\
\hline Microparsus vignaphillus (E.E. Blanchard, 1922 & 1 & - & - & - & - & 2 & - & 11 & 2 & - & 1 & 17 \\
\hline Myzocallis castanicola Baker, 1917 & - & - & - & - & - & 1 & - & - & - & - & 2 & 3 \\
\hline Myzus hemerocallis Takahashi, 1921 & - & - & - & - & - & - & 1 & - & 1 & - & - & 2 \\
\hline Myzus ornatus Laing, 1932 & - & 1 & - & - & 1 & 1 & 1 & - & 6 & - & 3 & 13 \\
\hline Myzus persicae (Sulzer, 1776) & 224 & 12 & 4 & - & 175 & 67 & 142 & 17 & 21 & - & 11 & 673 \\
\hline Ovatus crataegarius (Walker, 1850) & - & - & - & - & - & 2 & - & - & - & - & - & 2 \\
\hline Pemphigus populitransversus Riley, 1879 & 2 & - & - & 1 & 3 & 6 & 10 & - & 1 & - & 1 & 24 \\
\hline Pentalonia nigronervosa Coquerel, 1859 & 9 & 5 & 13 & 3 & 5 & 16 & 54 & 25 & 2 & - & - & 132 \\
\hline
\end{tabular}


Table I. Continued.

\begin{tabular}{|c|c|c|c|c|c|c|c|c|c|c|c|c|}
\hline \multirow{2}{*}{ Species } & \multicolumn{12}{|c|}{ Sites (Altitude $m$ a.s.l.) } \\
\hline & $\begin{array}{c}1 \\
(-10)\end{array}$ & $\begin{array}{c}2 \\
(10)\end{array}$ & $\begin{array}{c}3 \\
(20)\end{array}$ & $\begin{array}{c}4 \\
(65)\end{array}$ & $\begin{array}{c}5 \\
\quad(78)\end{array}$ & $\begin{array}{c}6 \\
(85)\end{array}$ & $\begin{array}{c}7 \\
(185)\end{array}$ & $\begin{array}{c}8 \\
(190)\end{array}$ & $\begin{array}{c}9 \\
(550)\end{array}$ & $\begin{array}{c}10 \\
(750)\end{array}$ & $\begin{array}{c}11 \\
(1000)\end{array}$ & Total \\
\hline Rhopalosiphina & 2 & - & - & - & - & 2 & 3 & - & - & - & - & 7 \\
\hline Rhopalosiphoninus latysiphon (Davidson, 1912) & - & - & - & - & 1 & - & 1 & - & - & - & 1 & 3 \\
\hline Rhopalosiphum maidis (Fitch, 1856) & 12 & 15 & 4 & 5 & 9 & 14 & 36 & 12 & 17 & - & 5 & 129 \\
\hline Rhopalosiphum nynphaeae (Linnaeus, 1761) & - & 1 & - & - & 15 & - & - & - & - & - & 1 & 17 \\
\hline Rhopalosiphum padi (Linnaeus, 1899) & 1 & 2 & 1 & 1 & 6 & 6 & 11 & - & - & 1 & 1 & 30 \\
\hline Rhopalosiphum rufiabdominalis (Sasaki, 1899) & 6 & 6 & 1 & 1 & 12 & 5 & 6 & 3 & 3 & - & 5 & 48 \\
\hline Schizaphis graminum (Rondani, (1847) 1852) & 1 & 4 & 1 & - & - & 1 & 1 & - & 1 & - & 6 & 15 \\
\hline Sipha flava (Forbes, 1884) & 1 & 3 & - & - & - & 2 & - & - & - & 1 & 3 & 10 \\
\hline Sitobion avenae (Fabricius, 1775) & - & - & - & - & 1 & 2 & - & - & 1 & - & 1 & 5 \\
\hline Sitobion lambersi David, 1956 & - & $=$ & - & 1 & - & - & - & - & - & - & 1 & 2 \\
\hline Sitobion luteum (Buckton, 1876) & - & - & - & - & - & 2 & - & - & - & - & 1 & 3 \\
\hline Sitobion salviae (Bartholomew, 1932) & 1 & - & - & - & - & - & - & - & - & - & - & 1 \\
\hline Tetraneura nigriabdominalis (Sasaki, 1899) & 27 & 17 & 1 & 1 & 2 & 97 & 49 & 21 & 46 & 13 & 45 & 319 \\
\hline Therioaphis trifolii (Monnel, 1882) & - & - & - & - & - & - & - & - & - & - & 1 & 1 \\
\hline Toxoptera aurantii (Boyer de Fonscolombe, 1907) & 125 & 57 & 58 & 42 & 3 & 108 & 74 & 37 & 48 & 42 & 2 & 596 \\
\hline Toxoptera citricidus (Kirkaldy, 1907) & 49 & 54 & 15 & 5 & - & 36 & 144 & 15 & 438 & 2 & 12 & 770 \\
\hline Tuberolachnus salignus (Gmeln, 1790) & - & - & - & - & - & 1 & - & - & - & 1 & - & 2 \\
\hline Uroleucon ambrosiae (Thomas, 1878) & 87 & 50 & 46 & 21 & 6 & 49 & 29 & 192 & 60 & 5 & 3 & 548 \\
\hline Uroleucon compositae (Theobald, 1915) & - & 1 & 2 & - & 1 & - & 2 & - & - & - & - & 6 \\
\hline Uroleucon erigeronensis (Thomas, 1878) & - & - & - & - & 2 & - & - & - & 1 & - & - & 3 \\
\hline Uroleucon gravicome (Patch, 1919) & - & - & - & - & - & - & - & - & - & - & 1 & 1 \\
\hline Uroleucon muermosum (Essig, 1953) & - & - & - & - & - & - & - & - & - & 1 & - & 1 \\
\hline Uroleucon sonchi (Linnaeus, 1767) & - & - & - & - & - & 6 & 1 & - & 16 & - & 2 & 25 \\
\hline Uroleucon sp. & - & - & - & - & - & - & - & 2 & - & - & - & 2 \\
\hline Total number of aphids/site & 974 & 760 & 404 & 289 & 1538 & 8351 & 1066 & 527 & 1018 & 256 & 352 & 8019 \\
\hline Percentage & 12.1 & 9.5 & 5.0 & 3.6 & 19.2 & 10.4 & 13.3 & 6.6 & 12.7 & 3.2 & 4.4 & 100 \\
\hline Number of species & 31 & 34 & 27 & 27 & 41 & 47 & 35 & 23 & 36 & 18 & 41 & 87 \\
\hline
\end{tabular}

Sites 5, 6 and 11 showed, in decreasing order, more aphid species (Tab. I), corresponding, respectively, to altitudes of 78,85 and $1000 \mathrm{~m}$ a.s.l. The first two sites are located in submontane ecosystems characterized by the overlap of two or more plant communities. It is interesting to note that the highest site, classified as uppermontane, had the second highest richness value, in spite of the relatively harsh climatic conditions at this site. BLACKMAN \& EASTOP (1984) mentioned that most aphid species are originated from the North Hemisphere, and are adapted to periodically cold winters. This could explain the low diversity of aphids in tropical regions, where most of the species are introduced.

As shown in table II, site 6 presented not only the highest diversity, but also the highest equitability, which expresses high homogeneity in the distribution of individuals among the species. The trap at site 6 was placed in an open area influenced by three different environments: primary vegetation, secondary vegetation in successional stages, and secondary vegetation under regular mowing. DIXON et al. (1987) and DiXON \& KINDLMANN (1990) stated that in places where plant diversity is high, aphid diversity tends to be lower. However, at site 6 there were three different environments, with high floral richness which probably accounted for the number of aphid species collected in the trap. ODUM (1983) mentioned that species diversity tends to increase during ecological succession, but this tendency does not necessarily occur at more mature stages, as in an established forest. Site 10 showed both low diversity and equitability due to the short period of collections at this site. 
Table II. Brillouin Index of diversity (HB) and equitability (E) for aphids collected with yellow pan traps in the Serra do Mar, Paraná, Brazil, from December 1993 to December 1994 (sites 01 to 09 and 11) and from April 1994 to December 1994 (site 10).

\begin{tabular}{cccccccccccc}
\hline Indexes & $1^{*}$ & 2 & 3 & 4 & 5 & 6 & 7 & 8 & 9 & 10 & 11 \\
& $(-10)$ & $(10)$ & $(20)$ & $(65)$ & $(78)$ & $(85)$ & $(185)$ & $(190)$ & $(550)$ & $(750)$ & $(1000)$ \\
\hline HB & 2,06 & 1,88 & 1,94 & 2,20 & 1,78 & 2,71 & 2,30 & 1,99 & 2,19 & 1,40 & 2,01 \\
E & 0,61 & 0,30 & 0,62 & 0,71 & 0,58 & 0,73 & 0,66 & 0,66 & 0,62 & 0,51 & 0,58 \\
\hline
\end{tabular}

*) Altitudinal values in meters above sea level.

\section{CONCLUSIONS}

The number of aphid species recorded in this research was expressive for the Brazilian aphidofauna, including four species new to the country: Carolinaia caricis Wilson, 1911, Uroleucon gravicorne (Patch, 1919), Dysaphis aucupariae (Buckton, 1879) e Uroleucon muermosum (Essig, 1953). The number of specimens was lower than that registered in some of the aphid surveys carried out in the metropolitan area of Curitiba, Paraná State; although, most of the specimens from these areas belonged to few common species.

The results of this study suggest that aphid richness and diversity are related to local floral structure and climate. A well defined altitudinal gradient in diversity or abundance was not observed in this study. However, anthropogenic disturbances, as regular mowing, could have disrupted this pattern. The results also reflect the complexity of aphid biology and ecology, which are influenced by the interaction between several biotic and abiotic factors and also by the limitation of the applied methodology and faunistic indexes. A more intensive survey of aphids on the plants and their relation with natural enemies in the complex Atlantic Rain Forest ecosystem will be investigated in the future.

\section{REFERENCES}

AgARWALA, B.K. \& M.R. GHOSH. 1985. Biogeographical considerations of Indian Aphididae (Homoptera). Ins. matsum. 31: 81-96.

Blackman, R.L. \& V.F. EAstop. 1984. Aphids on the World's Crops: An identification guide. Chichester, John A. Wiley \& Sons, 466p.

CosTA, C.L.; V.F. EASTOP \& R.L. BLACKMAN. 1993. Brazilian Aphidoidea: I. Key to families, subfamilies and account of the Phylloxeridae. Pesq. agropec. bras. 28: $197-215$.

COX, C.B. \& P.D. MOORE. 1993. Biogeography-An ecological and evolutionary approach. London, Blackwell Science Ltd., $5^{\text {th }}$ ed., 326p.

DixON, A.F.G. \& P. KindLMANN. 1990. Role of plant abundance in determining the abundance of herbivorous insects. Oecologia 83: 281-283.

DiXon, A.F.G.; P. KindLMANN; J. LEPS \& J. Holman. 1987. Why there are so few species of aphids, especially in the tropics. Amer. Nat. 129: 580-592.

FERnANDES, G.W. \& P.W. PRICE. 1991. Comparison of tropical and temperate galling species richness: the roles of environmental harshness and plant nutrient status, p.91-115. In: P.W. PRICE; T.M. LEWINSOHN; G.W. FERNANDES \& W.W. BENSON. Evolutionary Ecology in Tropical and Temperate Regions. New 
York, J. Wiley \& Sons Inc., 639p.

Holman, J. 1974. Los Áfidos de Cuba. La Habana, Instituto Cubano del Libro, $304 p$.

Huston, M. 1979. A general hypothesis of species diversity. Amer. Nat. 113: 81-101.

Instituto Agronômico do ParanÁ. 1994. Cartas Climáticas do Estado do Paraná. Londrina, Fundação Instituto Agronômico do Paraná, 49p.

LAWTON, J.H. 1983. Plant architecture and the diversity of phytophagous insects. Ann. Rev. Entomol. 28: 23-39.

MagurRan, A.E. 1988. Ecological diversity and its measurement. Princeton, Princeton University Press, $179 p$.

MARTIN, J.H. 1983. The identification of common aphid pests of tropical agriculture. Trop. Pest. Manage. 29: 395-411.

Millar, I.M. 1990. The Aphids (Homoptera: Aphididae) of South Africa. An Identification Guide. Entomology Memoir 78: 1-105.

ODUM, E.P. 1983. Ecologia. Rio de Janeiro, Ed. Guanabara, 434p.

PRANCE, G.T. 1995. A comparison of the efficacy of higher taxa and species numbers in the assessment of biodiversity in the neotropics, p.89-99. In: D.L. HAWKSWORTH (Ed.). Biodiversity - Measurement and Estimation. Oxford, The Royal Society, 140p.

Recebido em 30.VIII.1997; aceito em 05.XI.1998. 